\section{La música a l'escola: aproximació a l'educació musical actual a l'àrea metropolitana de barcelona}

UTE. Revista de Ciències de l'Educació

2020 núm. 3. Pàg. 7-21

ISSN 1135-1438. EISSN 2385-4731

http://revistes.publicacionsurv.cat/index.php/ute

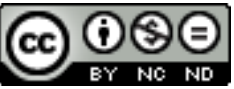

DOI: https://doi.org/ 10.17345/ute.2020.3

\author{
Mireia Moncada Pérez $\mathbb{D}^{\mathbb{D}}$, Albert Casals Ibáñez
}

Rebut: 31/07/2020 Acceptat: 21/12/2020

\begin{abstract}
Resumen
Els plantejaments musicals a les escoles de Catalunya són diversos, més encara en una època de gran heterogeneïtat de models i projectes escolars. En aquest context, el present article té com a objectiu mostrar una primera aproximació a la realitat musical escolar a partir d'un estudi exploratori en el marc dels Serveis Territorials del Vallès Occidental i del Consorci d'Educació de Barcelona. S'ha dut a terme un qüestionari que ha permès obtenir dades provinents de 135 escoles. El qüestionari comptava amb preguntes referents a la metodologia i estratègies didàctiques, a la formació, perfil i forma de treball de l'especialista i a l'ús de recursos TIC a l'aula. Els resultats mostren que els i les especialistes treballen a partir dels diversos contextos musicals d'aprenentatge, tot i que situen el bloc de cançó i veu com a eix, seguit del context d'audició. Així mateix, es constata que l'ús de recursos TIC és un àmbit poc explorat, en part a conseqüència de la manca de recursos i formació docent. Finalment, es discuteix sobre possibles tendències que situarien l'edat $i$ el gènere del professorat com a factor que condiciona determinats plantejaments musicals a l'escola.
\end{abstract}

Palabras clave: Educació musical, Escola Primària, TIC, Models educatius, Didàctica de la música.

\begin{abstract}
The musical approaches in the schools of Catalonia are diverse in an era of wide heterogeneity of school models and projects. In this context, this article aims to present a first approach to the musical realities in the schools from an exploratory study in the area of Vallès Occidental and Consorci d'Educació de Barcelona. A questionnaire has been carried out, which allowed to obtain data from 135 schools. The questionnaire asked for the different methodologies and didactic techniques together with the profile, work form and methods of the specialists and the use of ICT resources in classroom. The results show that the specialists start their work from different musical learning contexts, although they place the song and voice as the main axis, followed by the listening context. Likewise, it is noted that the use of ICT resources is an area that has not been widely explored much, partly as a result of the lack of resources and teacher training. To conclude, there are trends that deem the age and gender of teachers as a conditioning factor in the musical approaches at school.
\end{abstract}

Keywords: Musical education, Primary School, ICT, Educational models, Music didactics. 


\section{Introducción}

L'any 1990, amb l'aprovació de la Llei General d'Ordenació del Sistema Educatiu (LOGSE), va aparèixer la figura de l'especialista de música a Primària i va esdevenir obligatori disposar de, com a mínim, un mestre especialitzat en educació musical a cada centre. Aquest model segueix vigent actualment, i assegura una major qualitat dins de l'ensenyament musical escolar. Alhora, però, té altres implicacions, com per exemple l'augment de la dificultat de fer un treball holístic a causa del nombre de mestres que intervenen en un mateix grup-classe o l'habitual desaparició de la música com a recurs didàctic a l'aula ordinària, a excepció de la llengua estrangera (Casals, 2009). Al mateix temps que apareixia la figura de l'especialista de música, es posava en marxa el repte de mantenir una òptima coordinació entre l'especialista i el tutor o tutora, així com l'alineament de l'àrea de música amb la resta d'àrees. En el moment actual, aquest repte s'ha fet encara més necessari d'abordar atesa la diversitat de projectes escolars a les escoles catalanes, molts dels quals es basen en models d'ensenyament-aprenentatge globalitzadors o pluridisciplinaris.

En aquest marc, s'ha detectat una absència d'estudis i projectes que mostrin, des d'una perspectiva general, quina és la realitat musical escolar al territori català (Sambola i Casals, 2020). Tenint en compte aquest buit, es va dissenyar un projecte de recerca amb l'objectiu de descriure de quina manera s'està treballant la música a les escoles d'educació Primària. Com a part del projecte, en aquest article mostrarem els principals resultats de l'enquesta realitzada a escoles del Consorci d'Educació de Barcelona i del Servei Territorial del Vallès Occidental.

\section{La música a les escoles catalanes: panoràmica i plantejaments metodològics}

Actualment, el total d'hores mínimes globals que s'estableix al currículum que cal destinar a l'àrea d'educació artística -que inclou tant l'educació visual i plàstica com la música i la dansa-és de 525 hores. Resta a disposició dels centres distribuir el nombre d'hores totals entre les diverses disciplines per tal de poder garantir l'assoliment de les competències bàsiques. Això es tradueix en poc més d'una hora setmanal de mitjana dins de les 25 hores globals.

En consonància amb les tendències d'educació musical a gran part del món occidental (vegeu per exemple Bauer, 2020; o ljames, 2020), el currículum d'educació artística es sustenta en les competències pròpies de l'àrea, agrupades en tres dimensions que, des de la perspectiva de la música, equivalen a les tres dimensions clàssiques de la competència musical: escoltar, interpretar i crear (vegeu Paynter 1999; Malagarriga et al., 2010). S'explicita també que cal establir una metodologia en què es parteixi de l'experiència i de la pràctica artística, lligant-ho amb una reflexió i crítica, i contemplant el discent com a subjecte actiu de tot el procés. Així mateix, es proposa una avaluació continuada i sistemàtica que tingui presents aspectes com la sensibilitat $i$ la creativitat, que reculli les evidències d'aprenentatge, que sigui competencial i ajudi l'alumnat a ser conscient del procés d'aprenentatge i de vies per millorar.

Més enllà d'aquest marc normatiu, resulta complicat explicar el paper que té la música a les escoles de Catalunya a causa dels intensos processos de canvis pedagògics i de models escolars que s'estan produint, amb l'afegit del dèficit investigacions que explorin com els enfocaments metodològics treballats a la formació inicial s'assumeixen i es porten a la pràctica escolar (Cleaver i Ballantyne, 2014). De fet, ens trobem amb el fet que hi ha molt pocs estudis enfocats a radiografiar la realitat musical escolar, cosa que dificulta obtenir una visió general ajustada i basada en dades. Dos dels escassos projectes que s'han enfocat a mostrar la realitat musical escolar de forma àmplia són els projectes Quinze anys d'educació musical a l'escola Primària i El impacto de la Educación Musical Escolar en la Sociedad y la Economía del Conocimiento (IMPACTMUS). 
Quinze anys d'educació musical a l'escola Primària (2009-2012) va ser un projecte liderat per la Dra. Mercè Vilar (2013) i que estava enfocat a observar què passava a les aules de música de les escoles d'arreu de Catalunya al mateix temps que reflexionava al voltant de què vol dir una educació musical de qualitat. En el seu plantejament emergeix la idea que els elements bàsics de l'educació musical haurien de ser coincidents en les diferents tipologies d'escoles, independentment del seu projecte educatiu. De forma molt sintètica, es podria dir que aquest enfocament hauria de ser competencial (basat en l'escoltar, l'interpretar i el crear) i sempre assumint la premissa que s'aprèn música fent música, dins d'uns contextos de pràctica establerts (Casals et al., 2014).

Per la seva banda, el projecte IMPACTMUS (2015-2018) va ser un projecte creat amb la finalitat de fer una mirada retrospectiva i prospectiva sobre l'educació musical obligatòria a l'Estat espanyol, destriant quins beneficis aporta l'educació musical i quins són els reptes als quals cal atendre (Serrano, 2017a). A partir dels resultats aportats (Aróstegui, en premsa; Pérez-Moreno i Carrillo, 2019), i seguint el que exposen Sambola i Casals (2020), es poden destacar algunes idees clau per entendre el present de l'educació musical i construir-ne el futur:

- L'educació musical a l'escola no es pot entendre com allò que passa dins de l'aula de música. Just al contrari, ha d'estar connectada amb l'entorn. En aquest sentit es fa palès l'augment de la presència i importància de la música comunitària o l'aprenentatge artístic lligat a l'acció socioeducativa.

- Aprendre música té a veure amb una àrea, però cal emmarcar-la dins d'una visió global de l'aprenentatge. La música a l'escola, per tant, es construeix lligada a conceptes com la transdisciplinarietat, la interdisciplinarietat, la visió educativa transversal o la integració curricular.

- La música, des de la perspectiva educativa, té sentit en si mateixa. Amb tot, es constata que el seu aprenentatge aporta també beneficis importants en moltes àrees del currículum i pot esdevenir una eina fonamental per a la creativitat, la cohesió social o el desenvolupament personal i emocional de tot l'alumnat.

- En el marc curricular actual, l'àrea de música és crucial per assegurar l'educació escènica en el marc escolar: pel fet d'incloure la dansa, pel component de posada en escena que el 'fer música' ha d'incloure i pel dèficit en la presència de les arts més escèniques (en especial, el teatre) en els projectes educatius de moltes escoles.

- En el moment present, es fa difícil entendre l'educació musical sense parlar de noves tecnologies.

A part d'aquests projectes, alguns estudis recents respecte a la relació entre la música escolar i els projectes educatius de les escoles, com el de Sambola I Casals (2020), aporten dades que suggereixen que la tipologia i metodologia d'escola incideixen en aspectes organitzatius i materials pel que fa a la música, però relativament poc en la seva didàctica. Aquest mateix estudi es planteja que queda molt camí per fer de cara al fet que escoles i professorat integrin realment les propostes innovadores (dins de la pròpia àrea $i$ en diàleg amb les altres) $i$, específicament, es constata que determinades metodologies tenen dificultats per incorporar-hi l'educació musical. La particularitat de la dimensió sonora $\mathrm{i}$ el fet que per poder fer música en conjunt o per aprofundir en determinades pràctiques requereixi d'un lideratge o d'un rol directiu per part de l'especialista de música -que sovint les metodologies innovadores no contemplen- serien algunes hipòtesis del perquè (com fèiem notar a Sambola i Casals, 2020). Malgrat tot, l'escassetat de recerques àmplies sobre la situació del binomi educació musical i escoles innovadores no permet establir un estat de la qüestió mínimament concloent. 


\section{L'especialista de música a l'escola}

En el moment actual, es fa difícil parlar de l'educació (musical) sense tenir en compte la digitalització educativa i les tecnologies musicals a l'abast (Bauer, 2020). De fet, el desenvolupament d'internet ha revolucionat el món de la música, i de manera especial, la indústria musical. Giráldez (2005) defensava que aquest fet ha d'impregnar de la mateixa manera l'educació musical.

De forma genèrica, sembla que la tendència de les polítiques educatives al nostre context ens encamina a disminuir més que no pas ampliar el temps dedicat a l'àrea de música a les etapes obligatòries. Aquest fet ha portat a molts docents a qüestionar-se si és interessant, educativament parlant, invertir temps a introduir i utilitzar les TIC (Serrano, 2017b). Des de la posició contrària, convé tenir en compte les potencialitats de l'ús d'aquests recursos a l'aula de música implementades per Ufartes (2016) o recollides per Masdéu (2018), entre d'altres. Precisament seguint l'anàlisi que en fa Masdéu (2018), podem establir alguns aspectes en què les TIC donarien suport a la millora de les pràctiques docents. En primer lloc, poden ajudar a enriquir l'experiència musical dins de l'aula i facilitar tasques de gestió. Permeten, a més, ampliar el temps relatiu als processos d'instrucció i aprenentatge musical i possibiliten que cada alumne treballi en funció del propi ritme d'aprenentatge. Entre d'altres, fomenten l'aprenentatge actiu i la construcció del coneixement, l'exploració per part dels infants, la creativitat, la imaginació i la innovació musical de l'alumnat.

També en aquesta línia, Serrano (2017b) exposa que l'ús de les TIC pot aportar efectes positius en el comportament, la motivació, la responsabilitat, el treball en equip i el desenvolupament de competències comunicatives. Tot això propicia que el professorat busqui introduir-les cada vegada amb més freqüència $\mathrm{i}$ amb major qualitat a les seves assignatures, i que les administracions promocionin aquesta integració, oferint equipament en TIC i formació per al professorat, tot i que en moltes ocasions encara no s'han aconseguit uns resultats òptims (Guerrero, 2014).

Les administracions educatives potencien la producció de materials i recursos tecnològics, tot i que la inclusió d'aquests recursos no genera en si mateixa una bona pràctica educativa, sinó que depèn de l'aplicació metodològica que se'n faci. Masdéu (2018), de fet, afirma que és un error pensar que el sol fet d'incorporar les noves tecnologies a l'aula millorarà la qualitat i eficàcia dels aprenentatges, atès que la seva inclusió és un procés complex i només tindrà un impacte significatiu en l'aprenentatge si són incorporades de manera reflexiva i planificada.

Giráldez (2010) defensa que les TIC no han de suplantar tota la feina que es realitza a l'àrea de música, sinó complementar-la i enriquir-la. Canales i Marquès (2007) afegeixen que, a més, les TIC en l'àmbit escolar han d'ajudar a assolir els objectius de forma eficaç i han de ser eficients en aportar avantatges sobre els recursos tradicionals. Les TIC aplicades a les diferents àrees de coneixement han de permetre un canvi en les formes tradicionals d'ensenyament-aprenentatge que repercuteixi en la pràctica (Palomo et al., 2006) i porti al professorat a l'anàlisi reflexiva d'aquesta.

D'acord amb la síntesi que fa Serrano (2017b) de diversos autors, des d'aquesta reflexió pedagògica i essent fidel al model didàctic propi de l'especialista de música, caldrà determinar les eines tecnològiques que s'empraran i com s'integren en el procés educatiu. Per això, l'efectiva integració de la tecnologia hauria de conjurar la interacció entre tecnologia, contingut curricular i pedagogia (en la línia de Bauer, 2020).

Finalment, insistir en el fet que un dels motius més habituals pels quals el professorat decideix no emprar les tecnologies a l'aula és la manca de coneixements i habilitats respecte d'aquestes (d'acord amb Hew i Brush, citats a Masdéu, 2018). No obstant això, Masdéu (2018) afegeix que les actituds, creences i experiències prèvies dels docents també juguen un paper decisiu en el procés d'integració de les 
tecnologies a l'aula. L'actitud positiva del professorat envers els recursos tecnològics, doncs, facilitarà la seva predisposició a l'hora d'integrar-los en la seva pràctica docent (Ramírez et al., 2012).

\section{Metodologia}

La investigació que es presenta tenia per objectiu fer una primera mirada general a l'educació musical a l'escola Primària a Catalunya, a partir de l'estudi de la realitat en dos Serveis Territorials de l'àmbit metropolità de Barcelona (Vallès Occidental i Consorci d'Educació de Barcelona). Es tractava, en conseqüència, de fer un estudi exploratori per detectar elements clau i possibles tendències de cara a dissenyar futures investigacions en el camp.

D'acord amb les fases que proposen Alaminos i Castejón (2006, p.30), a partir de l'objectiu es va:

- Prendre decisions sobre les variables d'estudi i sobre la mostra. En aquest cas, essent un estudi exploratori sense pretensió d'extreure'n generalitzacions, s'optà per una mostra no probabilística de conveniència (a partir de les respostes que es poguessin obtenir, però que representessin almenys un $20 \%$ dels centres potencials). Les variables es van establir dins de l'equip investigador, a partir d'estudis anteriors sobre l'educació musical a l'escola que havíem realitzat i que es fonamentaven en les bases de la didàctica de música (Casals et al., 2014; Sambola i Casals, 2020) així com de treballs específics sobre les TIC a l'educació (Coll, 2008; Masdéu, 2018).

- Construir un qüestionari configurat per vint-i-sis preguntes estructurades en els següents blocs: a) dades del centre, b) dades de l'especialista, i c) aprendre música a la teva escola. En aquest formulari es preguntava específicament sobre la metodologia i estratègies didàctiques presents a l'escola, la formació i perfil de l'especialista de música, i el paper de la música a l'escola. També s'indagava sobre la forma de treball a l'àrea de música, els recursos d'aula així com els recursos TIC i la participació en projectes escolars i interescolars des de l'àrea. Majoritàriament es tractava de preguntes que calia respondre a través d'una escala de Likert, tot i que també n'hi havia algunes de resposta oberta i d'altres de tancades (de resposta única o de resposta múltiple). El qüestionari va ser sotmès a validació per part dues persones externes a partir de la qual es van ajustar sobretot les preguntes en relació a les TIC.

- Fer arribar el qüestionari a les gairebé 600 escoles del territori delimitat. Per a afavorir la resposta, es va optar per la utilització d'un formulari en línia. Aquest formulari, dissenyat amb Google Forms, va ser enviat a tots els centres d'Educació Infantil i Primària dels Serveis Territorials del Vallès Occidental (250) i del Consorci d'Educació de Barcelona (348) durant la tardor del 2019. Complementàriament, els investigadors van recórrer a l'ús de les xarxes socials i a llistes de correu de mestres de música (pròpies i de l'associació de mestres de música AEMCAT) per aconseguir el mínim de resposta que s'havia fixat.

- Preparar i analitzar les dades recollides, crear els gràfics corresponents (quan era pertinent) i establir els resultats. De les 154 respostes de professorat especialista de música, 135 van resultar vàlides. Aquestes corresponen a una mostra de professorat provinent de 126 escoles, que suposen un $21 \%$ del total dins dels territoris estudiats. Al Vallès Occidental es recolliren dades de 68 escoles, mentre que al Consorci d'Educació de Barcelona se n'obtingueren de 58 . Pel que fa a la titularitat del centre, predominen les escoles públiques, que suposen un $71,9 \%$ de la mostra, mentre que les escoles concertades i privades representen un $26,7 \%$ i $1,5 \%$ respectivament. 
En relació als anys d'experiència dels docents, predominen els mestres que tenen una trajectòria docent d'entre 10 i 20 anys (37\%), seguit dels especialistes que fa més de 20 anys que exerceixen aquesta professió (34,8\%). En percentatges menors es troben, en el següent ordre, els mestres novells amb una experiència d' 1 a 5 anys $(15,6 \%) \mathrm{i}$, per últim, els mestres amb una experiència de 5 a 10 anys $(12,6 \%)$.

Respecte del gènere del professorat que ha respost l'enquesta, convé destacar la diferència entre el nombre de dones, corresponent al $82,2 \%$ dels especialistes, davant del 17,8\% d'homes. Aquest percentatge és bastant similar al del total d'especialistes de les comarques estudiades, ja que només hi ha una variació d'un $6 \%$ entre ambdós gèneres .

- Interpretar i discutir els resultats per redactar-ne l'informe final.

\section{Resultats}

A continuació es presenten els resultats obtinguts amb relació a les diverses temàtiques que abordava el qüestionari, distribuïts en tres apartats. El primer comprèn aspectes generals en relació al plantejament de la música en el context escolar actual. El segon apartat es fixa de forma més concreta en el treball musical en els diversos contextos d'aprenentatge basats en la pràctica musical. I finalment, el darrer apartat es centra específicament en l'ús de les noves tecnologies en el treball musical a l'aula.

\subsection{El plantejament pedagògic a l'escola i a l'aula de música}

Els dos següents paràgrafs fan referència a metodologies i estratègies didàctiques presents a l'escola, en general. Es va demanar al professorat especialista que seleccionés, d'entre les opcions proposades, les que més definien la forma de treball del centre per poder establir una comparativa entre la línia metodològica d'escola i la forma de treballar a l'aula de música.

Entre les metodologies o estratègies didàctiques més presents a l'escola, destaquen, en aquest ordre: 1) el treball cooperatiu i/o collaboratiu; 2) el treball per projectes; 3) els tallers, hort i/o laboratoris; 4) el treball amb fitxes i/o llibres de text; i 5) els ambients o espais de lliure circulació. Cal destacar que un $50 \%$ dels mestres selecciona el treball amb fitxes i/o llibres de text com a suport al qual recorren, encara que no sigui el recurs més freqüent. Els resultats a l'àrea de música són significativament diferents, ja que únicament un $13 \%$ indica que empra el llibre i un $37 \%$ dels mestres fan servir dossier, llibreta o fulls pentagramats.

Centrant-nos en l'aula de música, els recursos més emprats, en ordre descendent, són: youtube; instrumental Orff; projector; instrument harmònic (piano, teclat, guitarra, acordió); musicogrames i pissarra i, per últim, flauta / flabiol. Tot i que aparentment les tecnologies estan molt presents (youtube i el projector estan als primers llocs), només un 13\% dels especialistes fa servir iPad o tauletes tàctils.

No tots els especialistes han indicat una resposta clara respecte del paper de la música dins del marc escolar i a la vinculació amb altres àrees. Així i tot, un $25 \%$ ha explicitat que connecta amb altres àrees, un $35 \%$ afirma que ho fa de manera puntual i un $14 \%$ indica que la seva àrea és una assignatura aïllada.

D'entre els projectes interescolars musicals en els quals participa l'escola, destaquen les cantates, amb una participació del $59 \%$ de les escoles (sobretot a través del projecte Cantània de L'Auditori de Barcelona), i projectes de dansa, com el Dansa Ara, amb un 35\% de centres implicats. Només un 7\% dels especialistes explicita la participació en projectes de pràctica instrumental i un $9 \%$ en el projecte de creació Els compositors entren a l'aula, ofert per L'Auditori de Barcelona. 
Un 52\% dels especialistes indica la participació en els projectes interns de l'escola, entre els quals destaquen els concerts escolars en un $38 \%$ dels casos i les festes escolars, amb un percentatge del $26 \%$ sobre el total de centres.

\subsection{El treball musical: els contextos d'aprenentatge i la lectoescriptura musical}

A continuació es presenta breument en quina mesura els i les especialistes de música consideren important el treball dels diferents contextos d'aprenentatge, essent 1 la negació de la seva importància i 6 la màxima valoració. Complementàriament es pregunta sobre el paper de la lectoescriptura musical.

En relació a cançó i veu (Figura 1), les dades mostren una innegable importància del bloc de cançó i veu: només 8 respostes (5,9\%) no se situen als valors més alts. I dos de cada tres dels enquestats ho situen com un context de màxima importància.

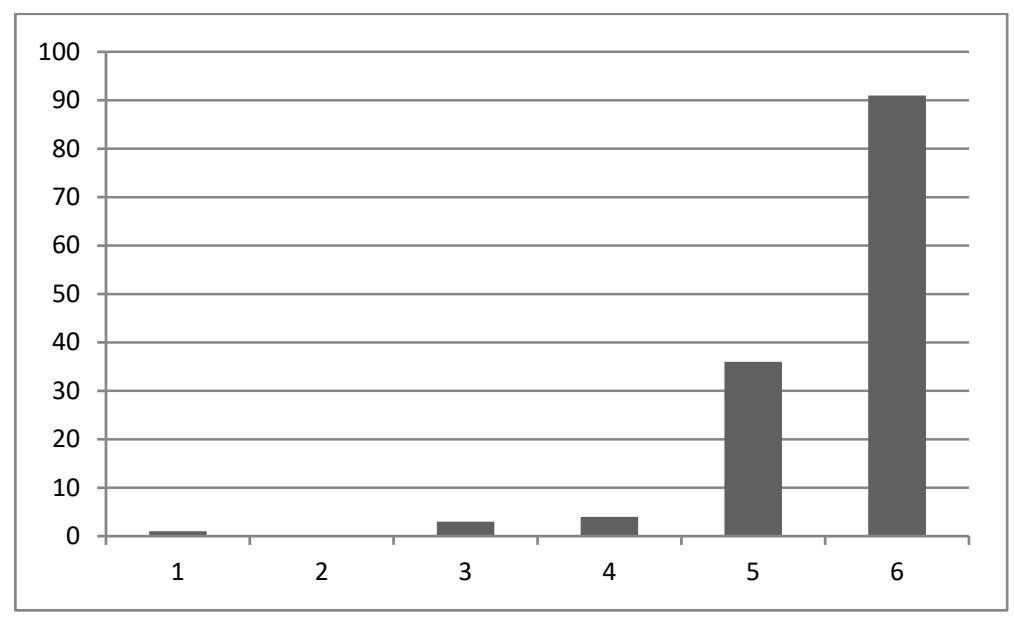

Figura 1. Consideració del context de cançó i veu

Tot i que la gràfica sobre la pràctica instrumental (Figura 2) no és tan explícita com l'anterior, també mostra una gran importància d'aquest context de treball a criteri dels mestres que van respondre l'enquesta. Gairebé la meitat dels especialistes li donen una puntuació de 5 sobre 6, i la resta de mestres li atorguen una importància d'entre 4 i 6 . Només un $7 \%$ dels especialistes considera que té poca importància.

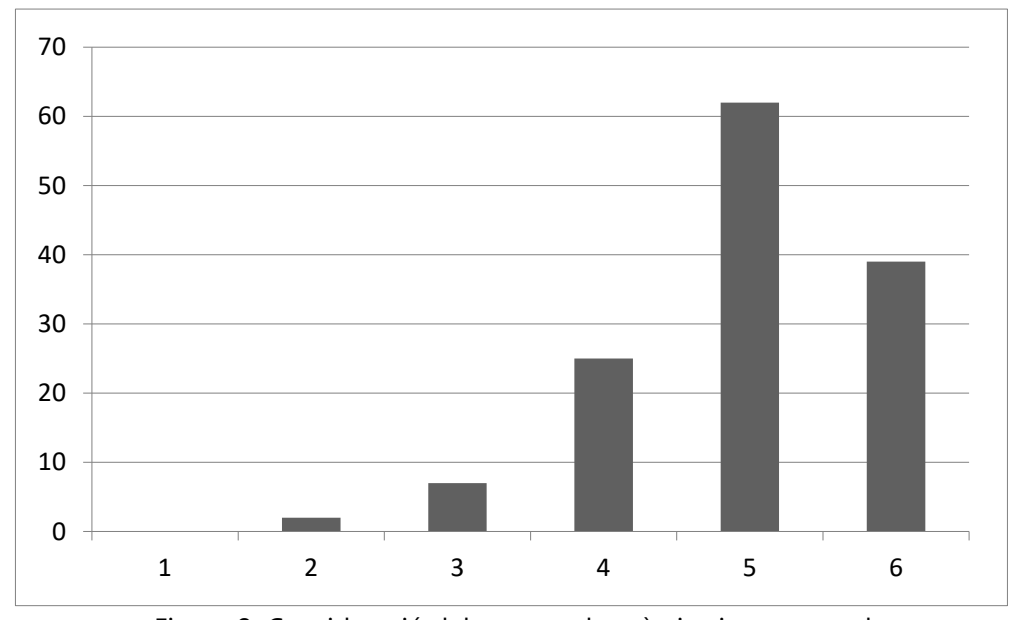

Figura 2. Consideració del context de pràctica instrumental

Afinant una mica més, cal esmentar que les escoles que participen en projectes de pràctica instrumental solen treballar la flauta o el flabiol a l'escola i són escoles públiques de la zona de Terrassa i Sabadell. El 
fet que predominin les escoles d'aquesta zona pot tenir a veure amb la proximitat amb el projecte Donem la llauna, que s'ofereix des de la Casa de la Música de Terrassa, o amb el projecte El flabiol a l'escola, implementat sobretot a Sabadell.

En la gràfica següent (Figura 3) es pot observar l'acord implícit que hi ha entre els especialistes de música pel que fa a la importància de l'audició dins de l'àrea. Pràcticament tots els especialistes de música li atorguen una importància d'entre 4 i 6 , i només un $3 \%$ la situen per sota de 4 . Aquesta representació indica que el context en qüestió té un pes molt important dins del treball que es fa a l'àrea de música.

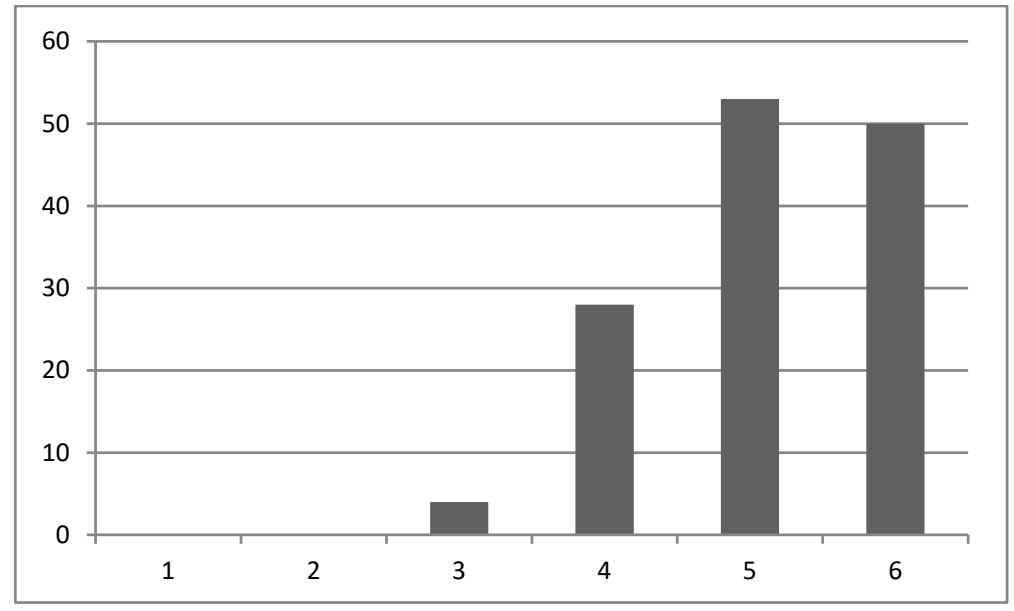

Figura 3. Consideració del context d'audició

En general, el treball de dansa i moviment és considerat com a rellevant (Figura 4). Un $80 \%$ dels especialistes el situa entre el 5 i el 6, un 14\% li dóna una importància de 4 i menys d'un $6 \%$ dels especialistes el situa entre l' 1 i el 3.

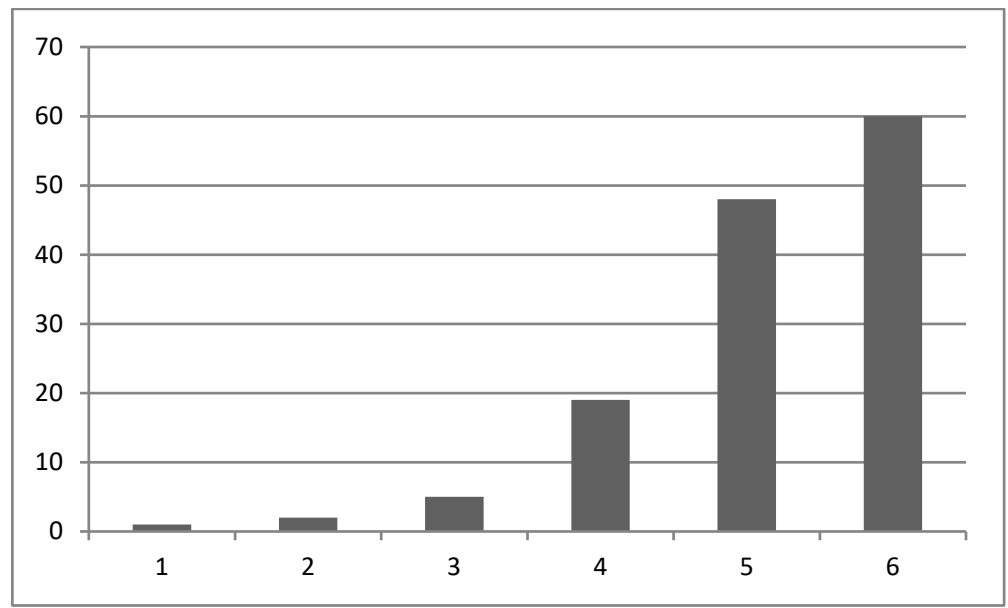

Figura 4: Consideració del context de dansa i moviment

En aquest punt convé destacar que s'ha pogut observar que el professorat especialista que participa en projectes de dansa -principalment interescolars- i que el professorat que més importància atorga a aquest bloc solen ser dones que treballen al Barcelonès. Cal fer notar que a Barcelona s'hi desenvolupen grans projectes vinculats a aquest context d'aprenentatge, com és el cas de Dansa Ara, en el qual hi participen un nombre molt elevat d'escoles de la ciutat.

En el bloc de creació es pot observar una gràfica més dispersa (Figura 5) i, per tant, emergeix un acord més diluït que en altres contextos d'aprenentatge. Tot i això, la majoria dels especialistes de música el consideren important, ja que gairebé un 38\% li concedeix una importància de 5, un 30\% de 6 i un 21\% de $4 . L^{\prime} 11 \%$ restant consideren que té una rellevància d'entre 2 i 3. 


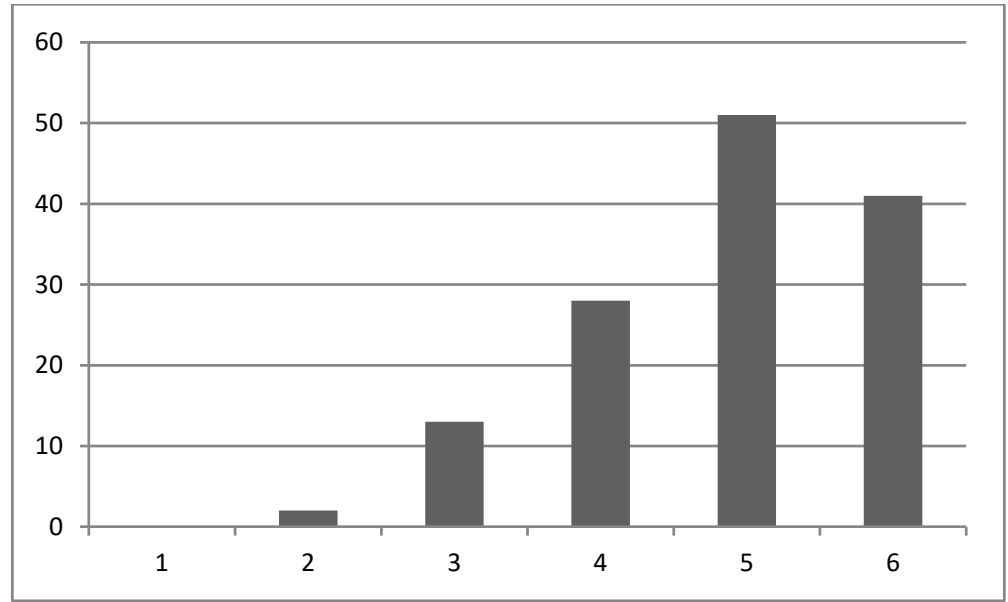

Figura 5. Consideració del context de creació

Si es creuen dades, es veu que les escoles que donen un gran pes a la creació i participen en projectes d'aquesta tipologia no solen utilitzar ni dossier, ni llibreta ni llibres de text a l'àrea de música. També es caracteritzen per tenir una gran presència de la música a l'escola i aquesta sol connectar amb altres àrees de coneixement. A més, solen ser escoles que participen en diversos projectes interescolars. Sembla ser, per tant, que les escoles en les quals des de l'àrea de música es fa un treball en profunditat del bloc de creació, la música sol tenir una presència destacada tant en activitats dins com fora de l'escola.

En contrast amb aquest consens majoritari entorn de la importància dels diversos contextos d'aprenentatge, en relació amb el treball de la lectoescriptura musical s'aprecien discrepàncies que apareixen reflectides a la gràfica següent (Figura 6). La majoria dels especialistes se situen entre el 3 i el 5 , essent el 4 el nombre amb el percentatge més alt. S'ha constatat que entre les escoles que atorguen molta importància a aquest bloc de treball i empren llibre a l'aula, predominen les escoles concertades dins del total de la mostra.

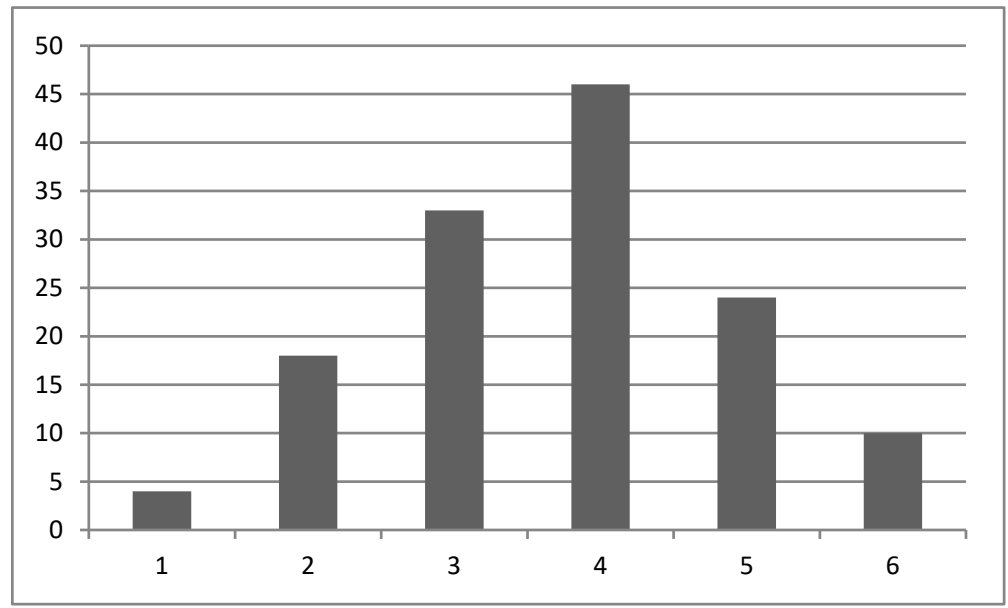

Figura 6. Consideració de la lectoescriptura

\subsection{L'ús de les TIC a l'àrea de música}

Totes les respostes que tenen a veure amb aquest apartat es decanten cap a la no utilització dels recursos tecnològics, a excepció de les eines d'enregistrament de so, que s'erigeixen com els més emprats. A 
continuació es presenten dues gràfiques contrastades entre si. A la Figura 7 es mostren les respostes referents a la freqüència d'ús d'instruments d'enregistrament de so: un $57 \%$ dels mestres en fa un ús molt poc freqüent, mentre que un $20 \%$ en fa servir de forma esporàdica i un $23 \%$ en fa un ús freqüent. Cal remarcar que s'inclouen aquí no només la utilització de softwares específics o aparells d'alta qualitat sinó també aplicacions tan accessibles com la càmera o l'enregistrament d'àudio que porten tots els telèfons mòbils.

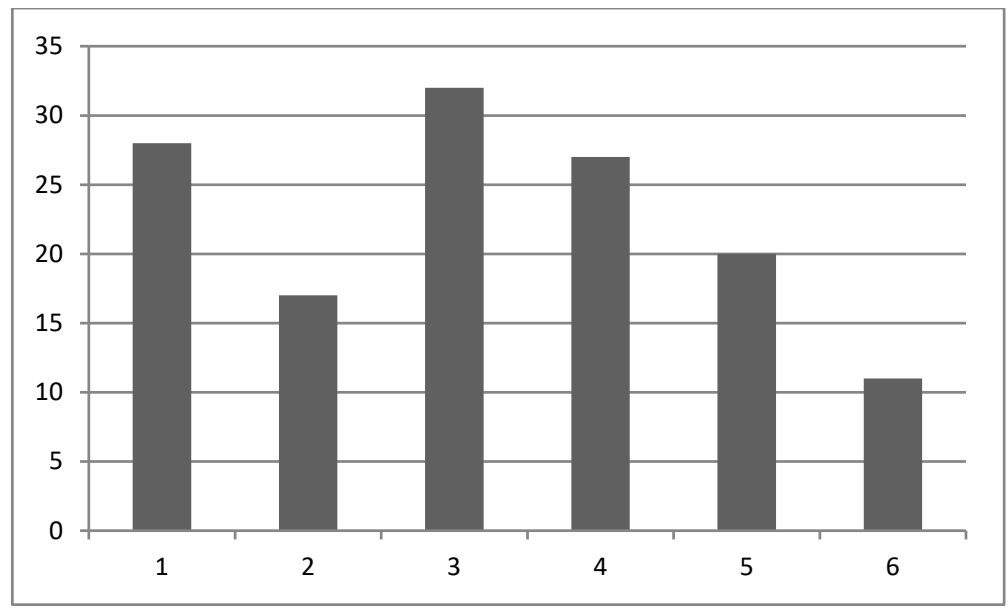

Figura 7. Freqüència d'ús d'instruments d'enregistrament de so

En canvi, l'ús de recursos TIC per a la composició (com podria ser per exemple Garageband) és pràcticament inexistent (Figura 8): gairebé un $85 \%$ dels especialistes assegura no fer-ho servir, un $10 \%$ ho fa servir de forma puntual i aproximadament un $5 \%$ afirma fer-ho servir de forma freqüent.

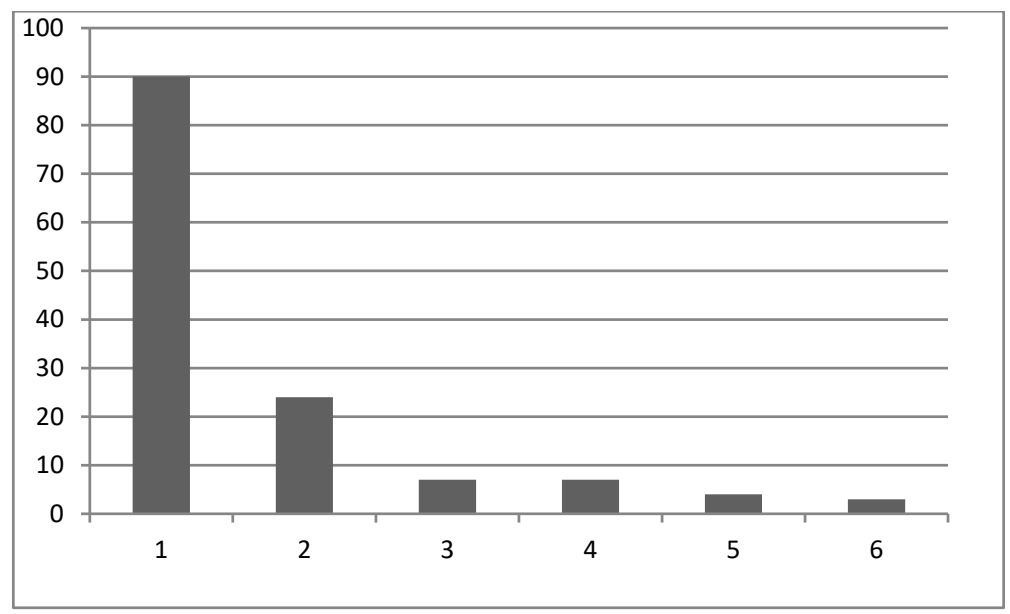

Figura 8. Freqüència d'ús de recursos TIC per a la composició

Pel que fa al perfil, es constata que, dins del baix percentatge d'ús de recursos TIC a l'aula, la majoria d'homes especialistes de música que porten una trajectòria docent d'entre 10 i 20 anys afirmen emprar recursos TIC com a eina de treball a l'àrea de música. En paral-lel, el perfil del professorat que afirmar emprar més l'iPad o les tauletes tàctils a les aules és el d'aquells especialistes que porten una trajectòria docent d'entre 1 i 10 anys.

Per últim, davant les preguntes sobre l'ús de noves tecnologies, molts mestres argumenten que els falta formació i recursos per poder-les implementar a l'aula. 


\section{Discussió}

El present article plantejava aproximar-nos a com s'està treballant la música a les escoles d'educació Primària a partir d'una mostra de conveniència realitzada dins de l'àrea metropolitana de Barcelona. Els resultats no són representatius ni generalitzables, però ens permeten detectar alguns aspectes a tenir en compte en futurs estudis, com veurem a continuació.

Cal destacar que, malgrat trobar-nos en un context amb una àmplia diversitat de models escolars, la radiografia que s'extreu ens mostra uns elements bàsics molt compartits entre els especialistes de música (destacant els contextos d'aprenentatge en què es basen i el poc ús de les TIC). Al mateix temps, reflecteix la riquesa de recursos i possibilitats de treball musicals existents. Finalment, ens dibuixen certes tendències o perfils en alguns sentits $i$ en què la variable gènere o edat hi té importància. Vegem-ho amb més detall.

En primer lloc, quan comparem les metodologies generals d'escola amb la forma de treballar la música al centre, s'observa que en molts casos no existeix una relació directa. Sambola i Casals (2020) ja feien notar que la formació i el perfil del professorat de música determina, en gran manera, el pes i definició que la música té dins del projecte escolar de cada centre. Espigares, García, Tejada i Rebollo (citats a Serrano, 2017b) sostenen també que el model didàctic de l'especialista determina decisivament els continguts musicals a abordar, la forma de treballar-los i el rol que ocupen alumnat i professorat en el procés. Perquè, com diu Regelski (2009), "és habitual que als professors de música se'ls reconegui una autonomia que s'acostuma a traduir en una idiosincràsia en el que al currículum i la pedagogia es refereix" (p.22).

En segon lloc, la fotografia obtinguda suggereix que encara són poques les escoles en què la música connecta de forma efectiva amb altres àrees de coneixement. Malagarriga et al. (2013) afirmen que cal que la música s'entengui, es visqui, es comprengui, també en relació amb altres àrees de coneixement, en altres situacions vitals o en altres contextos que depassen la classe de música, i que comparteixi amb elles tant els aspectes culturals, com els didàctics i pedagògics. El sistema educatiu està molt compartimentat i, sobretot a Primària, el fet que l'educació musical estigui encomanada a un mestre especialista, no afavoreix la possibilitat de connectar-la al desenvolupament del conjunt de competències bàsiques. Però és interessant constatar que els resultats indiquen que en aquelles escoles on la creació és un eix important del treball musical, aquesta àrea sol tenir molta presència dins del centre i acostuma a connectar amb altres àrees de coneixement.

En tercer Iloc, s'ha constatat que la majoria dels i les especialistes de música situen el context de la cançó i la veu com a base de l'aprenentatge musical, seguit del bloc d'audició. Són molts els pedagogs que al llarg de la història han justificat el cant i l'educació de l'oïda com a eixos de l'aprenentatge musical i per al desenvolupament de la sensorialitat musical (Kodály, Willems, Orff, Ward, en l'àmbit internacional, o Llongueres, Borgunyó i Ireneu Segarra en el context català).

Cantar és un vehicle privilegiat per iniciar-se en la música o, dit d'una altra forma, cantar -i l'ús de la veu en general- és el principal context musical a partir del qual viure i aprendre música:

El cant, la pràctica de cançons, constitueix la forma més espontània, natural i més espontània, natural i de fàcil accés per a la pràctica interpretativa de la música en general i dels seus elements constitutius. Afavoreix, a més, altres aspectes educatius com la socialització per mitjà de la seva pràctica colllectiva, el gust musical, etc. ${ }^{7}$ (Casals et al., 2014, p. 588)

O, com ens fa notar Henry (2001): 
El desenvolupament vocal dels infants és una àrea en què existeix una àmplia recerca. La tasca d'ensenyar els infants a cantar és un tot un repte $i$, com més aprenem, més ens adonem de la complexitat $i$ de la connexió que existeix entre el cant $i$ les altres àrees de desenvolupament musical.2 (p. 4)

Pel que fa a l'escolta, Malagarriga i Valls (2003) afirmen que:

Una educació integral de l'escolta comporta sempre posar l'infant en contacte amb l'obra d'art en la seva globalitat, fet que contribueix a enriquir la seva formació a tots els nivells: emocional, afectiu, psíquic, físic, intel-lectual, etc.; en moltes ocasions, suposa, a més, atendre aspectes més parcials com són la iniciació, el descobriment $i$, en alguns casos, el coneixement dels elements del llenguatge musical, sempre a partir d'un mateix principi: garantir que l'infant pugui experimentar, descobrir i expressar lliurement la seva percepció. 3 (pp. 17-18)

Amb tot, els resultats indiquen que l'alumnat de Primària generalment canta, escolta, toca instruments, balla i crea música. Hi ha força consens, en definitiva, al voltant de la idea que tots els contextos musicals d'aprenentatge han de ser presents a l'escola. Alhora, s'ha vist que els especialistes enquestats donen relativament poca importància -o almenys hi ha discrepància- en relació a la lectoescriptura musical. Aquestes dades fan pensar que segurament conceben que el treball d'educació musical a les escoles ha de basar-se en l'experiència, en la part sensorial i tendir cap a la praxis que defensa Regelski (2009).

A partir d'aquest marc general, cal subratllar algunes tendències que les dades insinuen i que caldria aprofundir-hi en estudis posteriors:

- Les dades obtingudes mostren que l'àmbit de noves tecnologies està encara poc explorat i poc implementat a les aules. Els especialistes insisteixen que els manca formació i els recursos tecnològics en si mateixos, d'acord amb el que exposen autors com Román (2017). Són, per tant, dos aspectes que convindria contemplar per aconseguir un grau d'ús més elevat. Convé recordar, però, que les actituds, creences $i$ experiències prèvies dels docents esdevenen un element clau a l'hora d'incloure aquests recursos a les aules (Masdéu, 2018) i que, per tant, l'actitud positiva del professorat envers el seu ús facilitarà la seva integració en la pràctica docent (Ramírez et al., 2012).

Per altra banda, la inclusió de les TIC no ha suposat fins al moment canvis metodològics significatius, sinó que s'ha utilitzat per reforçar la metodologia que es venia aplicant. Amb tot, segurament està essent infrautilitzat com a mitjà per crear xarxes d'aprenentatge entre el professorat i seria urgent potenciar una formació docent no només basada en competències tècnico-instrumentals sinó sobretot en les pedagògiques, que condueixin al professorat a la realització de bones pràctiques educatives (Serrano, 2017b).

- Les escoles que situen la dansa i el moviment com un dels blocs principals de treball i que, alhora, participen en projectes interescolars de dansa solen donar molt poca importància al treball de la lectoescriptura. Aquest fet pot fer pensar que es tracti d'una visió de l'educació musical en què el desenvolupament sensorial té molta importància, en què es posa de manifest la necessitat d'una educació musical basada en una experiència sensorial que parteix de la relació entre el cos, la música i el moviment (hereva de la línia proposada per Dalcroze que exposa Bachmann, 1998).

- Algunes dades fan necessari posar-se en alerta davant de possibles rols i estereotips de gènere encara presents en el món de l'educació i a la societat en general. S'ha comentat que el professorat que més importància dona a la dansa coincideix pràcticament per complet amb la figura de la dona. En canvi, quan s'analitza detalladament el perfil del professorat que incorpora 
recursos TIC a les aules, es detecta un increment del percentatge d'homes amb una trajectòria docent d'entre 10 i 20 anys respecte del total d'especialistes de música. Malgrat que les dades anteriors són poc esperançadores, l'avanç legislatiu i determinades iniciatives fan pensar que s'anirà produint una reducció de la "bretxa digital de gènere" (Barragán i Ruiz, 2013). Les generacions més joves han demostrat tenir un acostament a les TIC més igualitari entre dones i homes, fet que també es veu reflectit als resultats: el perfil del professorat que empra iPad o tauletes tàctils a les aules coincideix amb especialistes que porten una trajectòria docent d'entre $1 \mathrm{i} 10$ anys $\mathrm{i}$ en què la majoria són dones.

\section{Referències bibliogràfiques}

Alaminos, A., i Castejón, J. L. (2006). Elaboración, análisis e interpretación de encuestas, cuestionarios y escalas de opinión. Marfil / Universidad de Alicante.

Álvarez, T., Bertran, C., Álvarez, A. T., Bertran, C., Caballero, A., Cebrián, A., i Gómez, L. (2016). La música vista a través de futuros docentes: ¿la formación musical sirve a los maestros generalistas de Primaria? Artseduca, 14, 52-75. http://www.erevistes.uji.es/index.php/artseduca/article/view/2135

Aróstegui, J.L. (en premsa). La educación musical escolar y las demandas del sistema escolar: del arte por amor al arte a la sociedad y la economía del conocimiento. Octaedro.

Bachmann, M. L. (1998). La rítmica Jaques-Dalcroze: una educación por la música y para la música. Pirámide.

Barragán, R., i Ruiz, E. (2013). Brecha de género e inclusión digital. El potencial de las redes sociales en educación. Revista de currículum y formación del profesorado, 17(1), 309-323. http://www.ugr.es/ recfpro/rev171COL4.pdf

Bauer, W. I. (2020). Music learning today: Digital pedagogy for creating, performing, and responding to music. (2a Ed.). Oxford University Press.

Canales, R., i Marquès, P. (2007). Factores de buenas prácticas educativas con apoyo de las TIC. Análisis de su presencia en tres centros educativos. Educar, 39, 115-133.

https://doi.org/10.5565/rev/educar.164

Carrillo, C., i Vilar, M. (2012). Las competencias profesionales del profesorado de música opiniones de una muestra de docentes. Cultura y educación, 24(3), 319-335. https://doi.org/10.1174/113564012802845668

Casals, A. (2009). La cançó amb text improvisat: Disseny i experimentació d'una proposta interdisciplinària per a primària. Tesi doctoral, Universitat Autònoma de Barcelona. https://www.tdx.cat/handle/10803/4659

Casals, A., Carrillo, C., Valls, A., Vilar, M., i Ferrer, R. (2014). La concreción de un enfoque didáctico para la educación musical en Primaria. A E. Pérez i A. Álamo (eds.), Actas del III Congreso de Educación e Investigación Musical (pp. 586-594). Enclave Creativa Ediciones. 
Cleaver, D., i Ballantyne, J. (2014). Teachers' views of constructivist theory: A qualitative study illuminating relationships between epistemological understanding and music teaching practice. International Journal of Music Education, 32(2), 228-241. https://doi.org/10.1177\%2F0255761413508066

Coll, C. (2008). Aprender y enseñar con las TIC: expectativas, realidad y potencialidades. Boletín de la institución libre de enseñanza, 72, 7-40.

Giráldez, A. (2005). Internet y educación musical. Graó.

Giráldez, A. (2010). Repensar la educación musical en un mundo digital. A A. Giráldez (Ed.), Música. Complementos de formación disciplinar (pp. 73-100). Graó.

Guerrero, J. L. (2014). Evaluando actitudes y usos de las TIC del profesorado de música de educación secundaria. RIEM Revista Internacional de Educación Musical, 2, 10-23. https://doi.org/10.12967/RIEM-2014-2-p010-023

Henry, W. (2001). Vocal development in general music: Bringing two worlds together. General Music Today, 15(1), 4-8.

ljames, A.L. (2020). Teaching for Musical Understanding Through the Core Music Standards: Creating, Performing, and Responding in the Elementary Music Classroom. Tesi doctoral, Murray State University. https://digitalcommons.murraystate.edu/etd/170

Jorquera, M. C. (2010). Modelos didácticos en la enseñanza musical: el caso de la escuela española. Revista Musical Chilena, 64(214), 52-74.

Malagarriga, T., Gómez, I., i Viladot, L. (2010). Bases de la proposta. A T. Malagarriga, i M. Martínez (eds.), Tot es pot expressar amb música (pp. 15-75). DINSIC.

Malagarriga, T., i Valls, A. (2003). La audición musical en la Educación Infantil: propuestas didácticas. CEAC.

Malagarriga, T., Valls, A., i Vilar, M. (2013). La música a l'educació infantil i primària. A C.Calmell i L.Escudero (ed.), Actes del $2 n$ Congrés Internacional de Música de Catalunya (p. 117-120). Recuperat (31/07/20) de: http://grupsderecerca.uab.cat/musicaieducacio/content/documentslabast

Masdéu, E. (2018). MITEM, una propuesta de marco para la integración de las tecnologías en la educación musical. Universitas Tarraconensis. Revista de Ciències de l'Educació, 1(1), 20-31. https://doi.org/10.17345/ute.2018.1.1851

Palomo, R., Ruiz, J., i Sánchez, J. (2006). Las TIC como agente de innovación educativa. Consejería de Educación de la Junta de Andalucía. Recuperat (31/07/20) de: http://www.edubcn. cat/rcs_gene/11_TIC_como_agentes_innovacion.pdf

Paynter, J. (1999). Sonido y estructura. Akal. (Obra original publicada el 1992).

Pérez-Moreno, J., i Carrillo, C. (2019). El impacto de la educación musical escolar. Octaedro.

Ramírez, E., Cañedo, I., i Clemente, M. (2012). Las actitudes y creencias de los profesores de secundaria sobre el uso de Internet en sus clases. Comunicar: Revista científica iberoamericana de comunicación y educación, 38(19), 147-155. https://doi.org/10.3916/C38-2012-03-06 
Regelski, T. A. (2009). La música y la educación musical: Teoría y práctica para "marcar una diferencia". A D. K. Lines (Ed.), La educación musical para el nuevo milenio (pp. 21-47). Morata.

Román, M. (2017). Tecnología al servicio de la educación musical. Revista española de pedagogía, 75(268), 481-495. https://doi.org/10.22550/ REP75-3-2017-09

Sambola, A. M., i Casals, A. (2020). Qui decideix sobre la música a l'escola? Investigant l'equilibri entre perfils professionals i projectes escolars. Temps d'Educació, 58, 137-158. https://doi.org/10.1344/TE2020.58.11

Serrano, R. M. (2017a). Benefits and challenges of compulsory music education: the IMPACTMUS project. A T. IJdens, B. Bolder i E. Wagner (ed.), International Yearbook for Research in Arts Education 5/2017 (pp. 206-210). Waxmann Verlag.

Serrano, R. M. (2017b). Tecnología y educación musical obligatoria en España: referentes para la implementación de buenas prácticas. Revista Electrónica Complutense de Investigación en Educación Musical, 14, 153-169. http://dx.doi.org/10.5209/RECIEM.54848

Torres, J. L. (2011). Aplicación de las TIC en el aula de educación musical de la educación primaria. Eufonía: Didáctica de la música, 52, 63-70.

Ufartes, G. (2016). L'IPAD a l'àrea de música disseny, aplicació i anàlisi d'una proposta didàctica a l'educació primària. Tesi doctoral, Universitat Autònoma de Barcelona. http://hdl.handle.net/10803/367461

Vilar, M. (coord.) (2013). Quinze anys d'educació musical a l'escola primària. Informe de recerca. Cerdanyola del Vallès, ICE-UAB. Disponible (31/07/20) a: http://grupsderecerca.uab.cat/musicaieducacio/content/documents-labast

\footnotetext{
${ }^{1}$ Traducció dels autors: El canto, la práctica de canciones, constituye la forma más espontánea, natural y de fácil acceso para la práctica interpretativa de la música en general y de sus elementos constitutivos. Favorece además otros aspectos educativos, como la socialización por medio de su práctica colectiva, el gusto musical, etc.

2 Traducció dels autors: Child vocal development is one area for which an extensive body of research exists. The task to teaching young children to sing is incredibly challenging, and more we learn, the more we realize how complex and interconnected singing is with other areas of musical development.

${ }^{3}$ Traducció dels autors: Una educación integral de la escucha comporta siempre poner al niño en contacto con la obra de arte en su globalidad, lo que contribuye a enriquecer su formación en todos los niveles: emocional, afectivo, psíquico, físico, intelectual, etc.; en muchas ocasiones, supone, además, atender aspectos más parciales, como la iniciación, el descubrimiento y, en algunos casos, el conocimiento de los elementos del lenguaje musical, siempre a partir de un mismo principio: garantizar que el niño pueda experimentar, descubrir y expresar libremente su percepción.
} 